\title{
Identification of a growth suppression domain within the retinoblastoma gene product
}

\author{
Xiao-qiang Qin, Thomas Chittenden, David M. Livingston, and William G. Kaelin Jr. \\ Division of Neoplastic Disease Mechanisms, Dana Farber Cancer Institute, Harvard Medical School, Boston, Massachusetts \\ 02115 USA
}

To date, all naturally occurring retinoblastoma susceptibility gene (RB) mutations known to be compatible with stable protein expression map to the T/E1A and cellular protein-binding region (the "pocket" domain). This domain extends from residue 379 to 792 . When full-length RB and certain truncated forms were synthesized in human RB -1 - cells, we found that the minimal region necessary for overt growth suppression extended from residue 379 to 928 . A functional pocket domain and sequences extending from the carboxy-terminal boundary of the pocket to the carboxyl terminus of the protein were both necessary for growth suppression. Both sets of sequences were also required for E2F binding; hence, the two functions may be linked.

[Key Words: RB; T/E1A-binding domain; growth suppression; E2F; phosphorylation]

Received January 30, 1992; revised version accepted March 16, 1992.

Genetic analyses have shown that inactivation of a cellular gene, RB-1, is regularly linked to human retinal tumorigenesis (Knudson 1971; Benedict et al. 1983; Cavenee et al. 1983; Godbout et al. 1983; Sparkes et al. 1983; Friend et al. 1986; Fung et al. 1987; Lee et al. 1987a). RB-1 has therefore been termed a tumor suppressor gene. In keeping with this designation, reintroduction of the wild-type retinoblastoma susceptibility gene (RB) allele into tumor cells lacking RB function typically leads to growth suppression, for example, as manifested by failure to replicate on a plastic surface (Huang et al. 1988; Bookstein et al. 1990; Takahashi et al. 1991; J. DeCaprio and S. Friend, unpubl.).

The RB gene product undergoes cell cycle-dependent phosphorylation and dephosphorylation (Buchkovich et al. 1989; Chen et al. 1989; DeCaprio et al. 1989; Mihara et al. 1989; Xu et al. 1989; Ludlow et al. 1990/. These findings, and the preferential binding of the SV40-transforming protein, $\mathrm{T}$, to unphosphorylated $\mathrm{RB}$ (Ludlow et al. 1989, 1990), suggest that unphosphorylated RB may have certain growth-regulating functions, which phosphorylated RB lacks, and that certain aspects of $R B$ growth suppression function may be regulated by phosphorylation.

The minimal T/E1A-binding region of $\mathrm{RB}$ has been mapped to a segment spanning residues 379-792 ( $\mathrm{Hu}$ et al. 1990; Huang et al. 1990; Kaelin et al. 1990). This segment of the protein sequence is sufficient for binding to certain cellular proteins in vitro (Kaelin et al. 1991). The suspicion that RB binding to cellular proteins constitutes at least part of the mechanism by which RB op- erates in promoting growth control is underscored by the fact that naturally occurring, loss-of-function RB mutations, which do not destabilize the protein, regularly map to the T/E1A-binding region (the RB "pocket") and eliminate its known in vitro protein-binding function (Horowitz et al. 1989, 1990; Bookstein et al. 1990; Kaye et al. 1990; Shew et al. 1990a,b; Huang et al. 1991; Kaelin et al. 1991; Scheffner et al. 1991). Recent evidence suggests that the transcription factor E2F may form a complex with $\mathrm{RB}$ and that the pocket may play a major role in this process (Bagchi et al. 1991; Bandara and La Thangue 1991; Chellappan et al. 1991; Chittenden et al. 1991). This suggests that RB may function, at least in part, by regulating gene expression.

All of this notwithstanding, the suspicion that RB operates as a growth regulator by interacting with other proteins is based on circumstantial evidence obtained largely by in vitro experimental analyses or characterization of tumor-derived RB alleles. To provide a direct test of this hypothesis, we have performed experiments aimed at determining whether RB-mediated growth suppression is dependent on the function of its pocket, a known protein-binding domain.

\section{Results}

Expression of $R B$ polypeptides in vivo

The RB segment extending from residue 379 to the natural carboxyl terminus (928) is active in binding $\mathrm{T}$ and a series of defined cellular proteins, as shown by in vitro assays (Hu et al. 1990; Huang et al. 1990, 1991; Kaelin et 
Qin et al.

Figure 1. In vivo synthesis of truncated $\mathrm{RB}$ polypeptides as determined by Western blot analysis. (A) Analysis of cell lysates prepared from U20S cells transfected with pCMV-RB(379-928), pCMV-RB(379-928, $706 \mathrm{C} \rightarrow \mathrm{F}$ ), pCMV-RB, and pCMV-NeoBam (lanes 1-4, respectively), or SAOS2 cells transfected with the same set of plasmids (lanes 5-8, respectively) $17.5 \%$ SDSpolyacrylamide gel $\}$. $\{B \mid$ Analysis of cell lysates prepared from U20S cells transfected with pCMV-RB(379-792), pCMV$\mathrm{RB}\{379-792,706 \mathrm{C} \rightarrow \mathrm{F}\}$, and $\mathrm{pCMV}-$ $\mathrm{RB}(379-928)$ (lanes 1,2,5, respectively), or SAOS2 cells transfected with pCMV$\mathrm{RB}(379-792,706 \mathrm{C} \rightarrow \mathrm{F})$ and pCMV$\mathrm{RB}(379-792)$ (lanes 3,4, respectively) (10\% SDS-polyacrylamide gel). Filters were probed with an anti-RB antibody (XZ91), and antibody localization was determined colorimetrically.
A

A

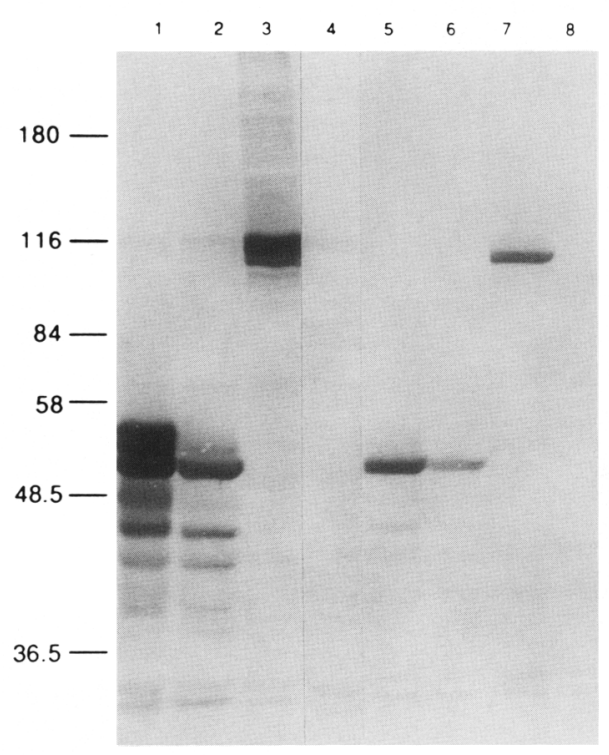

B

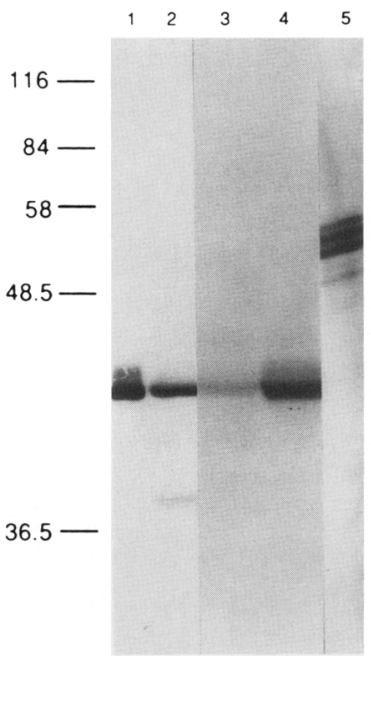

al. 1990, 1991; Chittenden et al. 1991; Ewen et al. 1992). The minimal pocket domain, $\mathrm{RB}(379-792\}$, is an internal segment of this RB fragment and is sufficient for $\mathrm{T}$ and cellular protein-RB complex formation in vitro (Kaelin et al. 1990, 1991). In preparation for the first set of experiments, $\mathrm{RB}(379-928)$ and a mutant derivative $\mathrm{RB}(379-928,706 \mathrm{C} \rightarrow \mathrm{F})$, the minimal pocket domain (379-792) and its corresponding mutant derivative $\mathrm{RB}(379-792,706 \mathrm{C} \rightarrow \mathrm{F})$, and full-length $\mathrm{RB}$, were subcloned into a eukaryotic expression vector, $\mathrm{pCMV}-\mathrm{Neo}-$ Bam (Baker et al. 1990). After transfection into two human osteosarcoma cell lines, U20S $(\mathrm{RB}+1+)$ and SAOS2 (RB $-/-$ ) (Lee et al. 1987b; Shew et al. 1990b), each plasmid gave rise to the synthesis of the expected $R B$ product (Fig. 1A,B), as measured in a transient expression assay. In U20S cells, $R B$ and $R b(379-928)$ appeared as a collection of differentially migrating SDS-gel bands (Fig. $1 \mathrm{~A}$, lanes 3 and 1, respectively). In contrast, only one major band of each species, that is, the fastest migrating one, was detected in SAOS2 cells (Fig. 1A, lanes 7 and 5, respectively). Unlike $R B(379-928)$ and full-length $R B$, the products of both the wild-type and mutant minimal pocket domain-encoding plasmids [RB(379-792) and $\mathrm{RB}(379-792,706 \mathrm{C} \rightarrow \mathrm{F})$, respectively] migrated largely as single bands after extraction from both cell lines (Fig. 1B, lanes 1-4; see Fig. 3B, lane 2, below).

\section{Phosphorylation of $R B$ derivatives expressed in $R B+/+$ and $R B-1-$ cell lines}

To probe the nature of the differentially migrating $R B$ species, immunoprecipitation and Western blot analyses were performed after parallel $\left[{ }^{32} \mathrm{P}\right]$ orthophosphate (Fig. $2 \mathrm{~A}, \mathrm{~B})$ and $\left[{ }^{35} \mathrm{~S}\right]$ methionine (Fig. $2 \mathrm{C}$ ) labeling of tran-

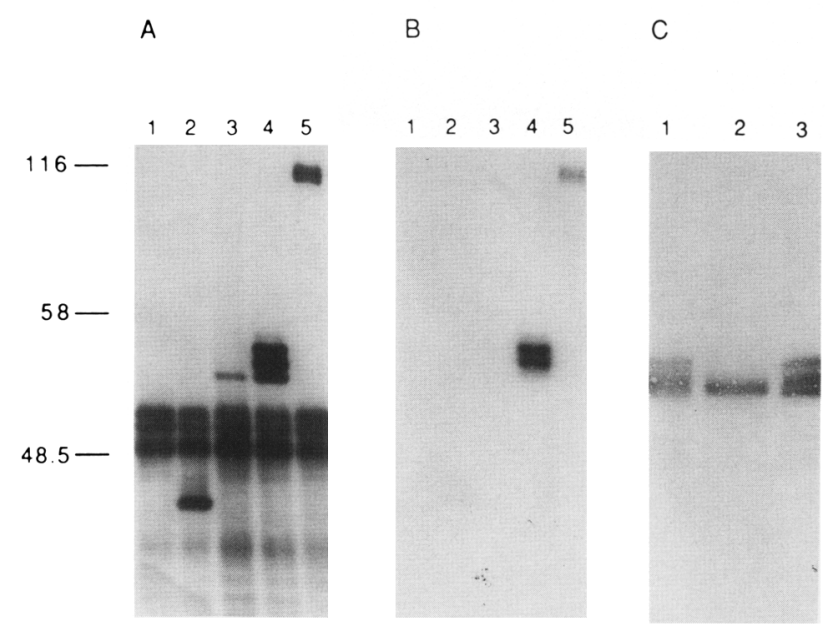

Figure 2. ${ }^{32} \mathrm{P}$-Labeling and phosphatase assay. U20S cells were metabolically labeled with either $\left[{ }^{32} \mathrm{P}\right]$ orthophosphate $\langle A, B\rangle$ or $\left[{ }^{35} S\right]$ methionine $(C)$. After immunoprecipitation with an antiRB antibody (XZ91), protein A-Sepharose-bound proteins were resolved in SDS-polyacrylamide gels, transferred to PVDF membranes, and detected either by immunoblotting with XZ91 $(A)$ or by autoradiography after blotting $(B, C)$. (A) (Lane 1$)$ U20S cells transfected with pCMV-Neo-Bam alone; (lane 2) pCMV$\mathrm{RB}(379-792)$; (lane 3) pCMV-RB(379-928, $706 \mathrm{C} \rightarrow \mathrm{F}$ ); (lane 4) pCMV-RB(379-928); and (lane 5) pCMV-RB. (B) Autoradiograph of the blot described in $A$. The film was exposed for 20 min without an intensifying screen. $(C)$ Phosphatase assay. Aliquots of a cell lysate prepared from U20S cells transfected with pCMV-RB(379-928) were immunoprecipitated with XZ91. Alkaline phosphatase treatment was performed in the presence or absence of phosphatase inhibitors (lanes 1,2, respectively). (Lane 3) A control in which no enzyme was added. The heavy, $\sim 48-$ to 52 -kD triplet noted in $A$ is immunoglobulin heavy chain. 
siently transfected U20S cells. The results indicate that the slower, and not the fastest, migrating RB(379-928) and full-length $R B$ species were apparently phosphorylated (cf. Fig. 2A and B). In contrast, as expected from an earlier study with full-length RB (Kaye et al. 1990), there was no apparent phosphorylation of $\mathrm{RB}(379-928,706$ $\mathrm{C} \rightarrow \mathrm{F}$ ), which migrated as a single band in these gels (Fig. 1A, lane 2; Fig. 2A, lane 3, and data not shown). Moreover, there was also no apparent phosphorylation of the $\mathrm{RB}(379-792)$ species in U20S cells, as shown in Figure $2, A$ and $B$ (lane 2 in each case).

The ${ }^{32} \mathrm{P}$-labeling experiment did not exclude the possibility that additional forms of post-translational modification contributed to the appearance of the slower migrating RB species. Therefore, the truncated RB species extending from residue 379 to 928 was subjected to exogenous phosphatase treatment in an effort to determine whether phosphate removal would eliminate any of the slower migrating bands observed in Figures 1 and 2. As shown in Figure 2C, such treatment specifically eliminated the slower migrating species. As demonstrated previously (Ludlow et al. 1989), phosphorylation is the basis for heterogenous migration of the full-length protein. The data shown in Figure $2 \mathrm{C}$ indicate that the same is true for the truncated $\mathrm{RB}$ product. It should also be noted that all newly synthesized RB species detected in SAOS2 cells appeared to be unphosphorylated, because they migrated as single bands (Fig. 1A, lanes 5-7), which comigrated with the apparently unphosphorylated RB species observed in U20S cells. They also failed to label with ${ }^{32} \mathrm{P}$, and their migration was not affected by phosphatase treatment (data not shown). Similar results were noted in two other RB-1- cell lines-the human osteosarcoma cell line, OHS50-T (Diller et al. 1990), and the human breast carcinoma cell line, MDA-MB-468
(Lee et al. 1988; T'Ang et al. 1988; Horowitz et al. 1990, and data not shown). We conclude from these findings that none of these three $\mathrm{RB}-1-$ cell lines efficiently phosphorylated the newly synthesized RB derivatives described here.

\section{All $R B$ species containing an intact pocket} and synthesized in vivo bind to SV4O T

To determine whether these various species, synthesized in vivo, could bind specifically to $T$, cell lysates were prepared from transiently transfected, $\left[{ }^{35} S\right\}$ methioninelabeled SAOS2 cells (Fig. 3A). Identical amounts of each lysate were mixed with aliquots of a lysate of MEFT $T$ cells (Ewen et al. 1989; Chen and Paucha 1990), a murine cell line that overproduces intact SV40 T. Immunoprecipitation with PAb419 (Harlow et al. 1981), an anti-T monoclonal antibody, showed that full-length $\mathrm{RB}$, $R B(379-928)$, and $R B(379-792)$ all coprecipitated with $T$ (Fig. 3A, lanes 3, 5, and 1, respectively). In another experiment, none of the products of transfection noted above were found to coprecipitate when incubated with lysates of the mouse cell lines A31 and MEF $\Psi$ K1 (data not shown). The former cell line produces no $T$, and the latter produces a mutant $\mathrm{T}$ species $(\mathrm{K} 1 \mathrm{~T})$ that can neither transform nor bind to RB (Kalderon and Smith 1984; DeCaprio et al. 1988; Chen and Paucha 1990!. Finally, where tested, the $706 \mathrm{C} \rightarrow \mathrm{F}$ derivatives of these truncated RB species also failed to bind to $\mathrm{T}$ (data not shown), in keeping with past results (Kaye et al. 1990; Kaelin et al. 1991). Therefore, binding of $T$ to $R B$ depended on the integrity of the RB pocket. Similar results were obtained using the cell lines U20S and OHS50-T (data not shown). Further immunoprecipitation and Western blot analysis using U20S cells, in which overt RB phosphorylation
A

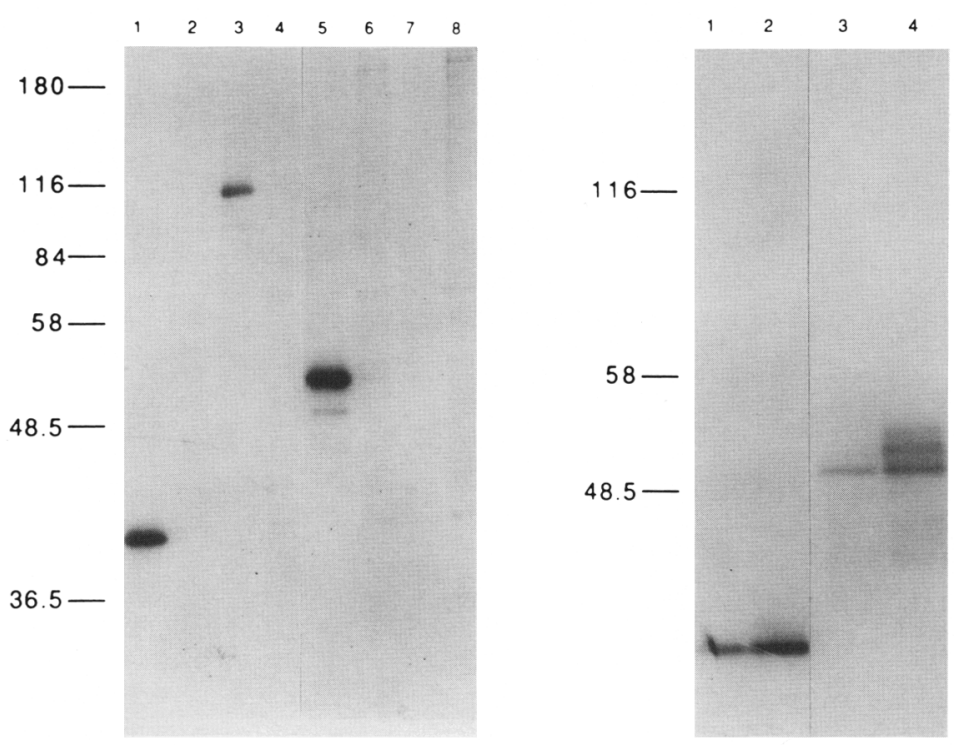

Figure 3. $\mathrm{T}$ binding. (A) $\left.{ }^{35} \mathrm{~S}\right]$ Methionine-labeled lysates prepared from various SAOS2 transfectants were incubated in the presence (lanes $1,3,5,7$ ) or absence (lanes $2,4,6,8$ ) of aliquots of unlabeled T-containing cell lysate and immunoprecipitated with a monoclonal antibody directed against $\mathrm{T}$ (PAb419). (Lanes 1,2) pCMVRB(379-792); (lanes 3,4) pCMV-RB; (lanes 5,6) pCMV$\mathrm{RB}(379-928)$; (lanes 7,8) pCMV-Neo-Bam. $(B) \mathrm{T}$ binds only unphosphorylated $\mathrm{RB}(379-928) .\left[{ }^{35} \mathrm{~S}\right]$ Methioninelabeled lysates, prepared from U20S cells transfected with pCMV-RB(379-792) (lanes 1,2) and pCMV$\mathrm{RB}(379-928)$ (lanes 3,4) were immunoprecipitated with PAb419 in the presence of $T$, as described above (lanes 1,3 ), or immunoprecipitated with XZ91 (lanes 2,4). Bound proteins were resolved in $7.5 \%$ polyacrylamide gels and detected by autoradiography. 
could be readily detected, indicated that $T$ bound only the unphosphorylated species of RB(379-928) (Fig. 3B, cf. lanes 3 and 4). The preference of $T$ for unphosphorylated RB has been described previously for full-length RB (Ludlow et al. 1989, 1990|. Taken together, these results indicate that after de novo synthesis, the specifically truncated $\mathrm{RB}$ species possessing an intact pocket can serve as specific targets for $\mathrm{T}$ binding. Furthermore, $\mathrm{T}$ can discriminate between the phosphorylated and unphosphorylated forms of either $\mathrm{RB}$ or $\mathrm{RB}(379-928)$, implying that the latter retains those sequences needed to render $\mathrm{RB}$ immune to $\mathrm{T}$ binding after phosphorylation.

\section{Nuclear localization of $R B$ \\ and its truncated derivatives}

Full-length RB is a nuclear protein whose growth suppressor functions may require interactions with nuclear elements such as certain transcription factors and nuclear tethering proteins not yet identified (Mittnacht and Weinberg 1991; Templeton et al. 1991). To determine the intracellular location of the truncated RB polypeptides after in vivo expression, immunofluorescence was performed with an anti-RB monoclonal antibody (XZ91 or XZ56). All of the wild-type and mutant RB derivatives described above were found to be primarily nuclear in location (Fig. 4).

\section{A truncated $R B$ polypeptide containing residues 379-928 can suppress cell growth}

To determine whether one or more of the various wildtype and mutant $\mathrm{RB}$ alleles described above could suppress the growth of a series of $\mathrm{RB}+/+$ and $\mathrm{RB}-/-$ cell lines, we used an assay described earlier by Baker et al. (1990) to measure growth suppression by p53 alleles. Here, the question was whether various RB cDNAs, when transfected in the presence of a neomycin resistance gene, would suppress the ability of recipient cells to form macroscopic, G418-resistant colonies. In the first group of growth-suppression assays, we transfected four plasmids: pCMV(Neo-Bam), the vector alone; pCMV-RB; pCMV-RB(379-928); and pCMV-RB(379$928,706 \mathrm{C} \rightarrow \mathrm{F}$ ) into SAOS2 and U20S cells. In the RBcontaining plasmids, the cDNA-coding unit was linked to a cytomegalovirus (CMV) promoter. As shown in Figure $5 \mathrm{~A}$, dramatic suppression of $\mathrm{G} 418^{\mathrm{r}}$ colony formation was observed in SAOS2 cells transfected by plasmids encoding either full-length $\mathrm{RB}$ or RB(379-928). No significant inhibition was noted with the $706 \mathrm{C} \rightarrow \mathrm{F}$ derivative of the latter. Furthermore, none of the relatively few colonies observed among the wild-type $\mathrm{RB}(379-928)$ transfectants gave rise to stable cell lines, whereas the colonies obtained with the point mutant derivative did so readily (data not shown). Finally, cells transfected with pCMV-RB or pCMV-RB(379-928), but not pCMV$\mathrm{RB}(379-928,706 \mathrm{C} \rightarrow \mathrm{F})$, repeatedly exhibited an increase in size, a phenotype suggestive of possible cell cycle arrest (Fig. 6, and data not shown). Pulse-chase experiments indicated that there was no significant dif- ference in the half-lives of the wild-type and the 706 $\mathrm{C} \rightarrow \mathrm{F}$ mutant derivative of $\mathrm{RB}(379-928)$ studied here (data not shown). Therefore, stability differences do not likely explain the observed differences in biological activity. To eliminate the possibility that these gross differences in growth inhibition were the result of more wild-type than mutant $\mathrm{RB}(379-928)$ being present in these cells after transfection, the experiment was repeated under conditions where similar amounts of the two proteins were present in transfected SAOS2 cells, as detected by Western blotting. Again, the wild-type $\mathrm{RB}(379-928)$-encoding plasmid suppressed colony formation, and the mutant $\mathrm{RB}(379-928,706 \mathrm{C} \rightarrow \mathrm{F})$ did not (data not shown).

The growth suppression assay was repeated using a plasmid containing a full-length RB cDNA encoding an $\mathrm{RB}$ protein with a pocket bearing a deletion that results from the loss of exon 22 (Horowitz et al. 1990; Kaelin et al. 1991). In keeping with the work of others (Horowitz et al. 1990; Templeton et al. 1991), this plasmid directed the synthesis of an apparently unphosphorylated nuclear protein as determined by Western blotting, orthophosphate labeling, and immunofluorescence (Fig. $4 \mathrm{H}$, and data not shown). No growth inhibition of SAOS2 was observed (data not shown), despite levels of exogenous $\mathrm{RB}$ expression equaling that seen with the $\mathrm{RB}(379-928)$ encoding plasmid (data not shown). Because previous results indicated that mutations in the pocket region inactivate its protein-binding function (Kaye et al. 1990; Chittenden et al. 1991; Kaelin et al. 1991), these data imply that this particular function of the pocket is linked to its growth-inhibiting action.

Analogous results were obtained with full-length $\mathrm{RB}$, $\mathrm{RB}(379-928)$, and its $706 \mathrm{C} \rightarrow \mathrm{F}$ derivative in OHS50- $\mathrm{T}$ cells (RB $-/-$ ) (data not shown). Unlike SAOS2 cells, in which an $\mathrm{RB}$ protein truncated at the carboxyl terminus can be detected (Shew et al. 1990b), this latter cell line produces no detectable RB protein (data not shown, and S. Friend, pers. comm.). Thus, the growth suppression observed in SAOS2 cells is not likely the result of complementation between the newly introduced, truncated $\mathrm{RB}$ species and the endogenous mutant RB protein.

Similar transfections were performed in U20S cells lan $\mathrm{RB}+1+$ osteogenic sarcoma line) with pCMV(NeoBam), pCMV-RB, pCMV-RB(379-928), and pCMV$\mathrm{RB}(379-928,706 \mathrm{C} \rightarrow \mathrm{F})$. In contrast to the results described above, none of the four plasmids transfected under conditions identical to those used in the SAOS2 experiments suppressed colony formation (data not shown).

The minimal $R B T / E 1 A$-binding domain is not sufficient to suppress cell growth

We then asked whether the pocket alone $(\mathrm{RB}$ residues 379-792) could suppress the growth of an RB - / - cell line. To this end, plasmids encoding wild-type and the $706 \mathrm{C} \rightarrow \mathrm{F}$ mutant derivative of the minimal pocket domain (379-792) were transfected into SAOS2 cells along with a plasmid encoding the full-length RB protein. As 

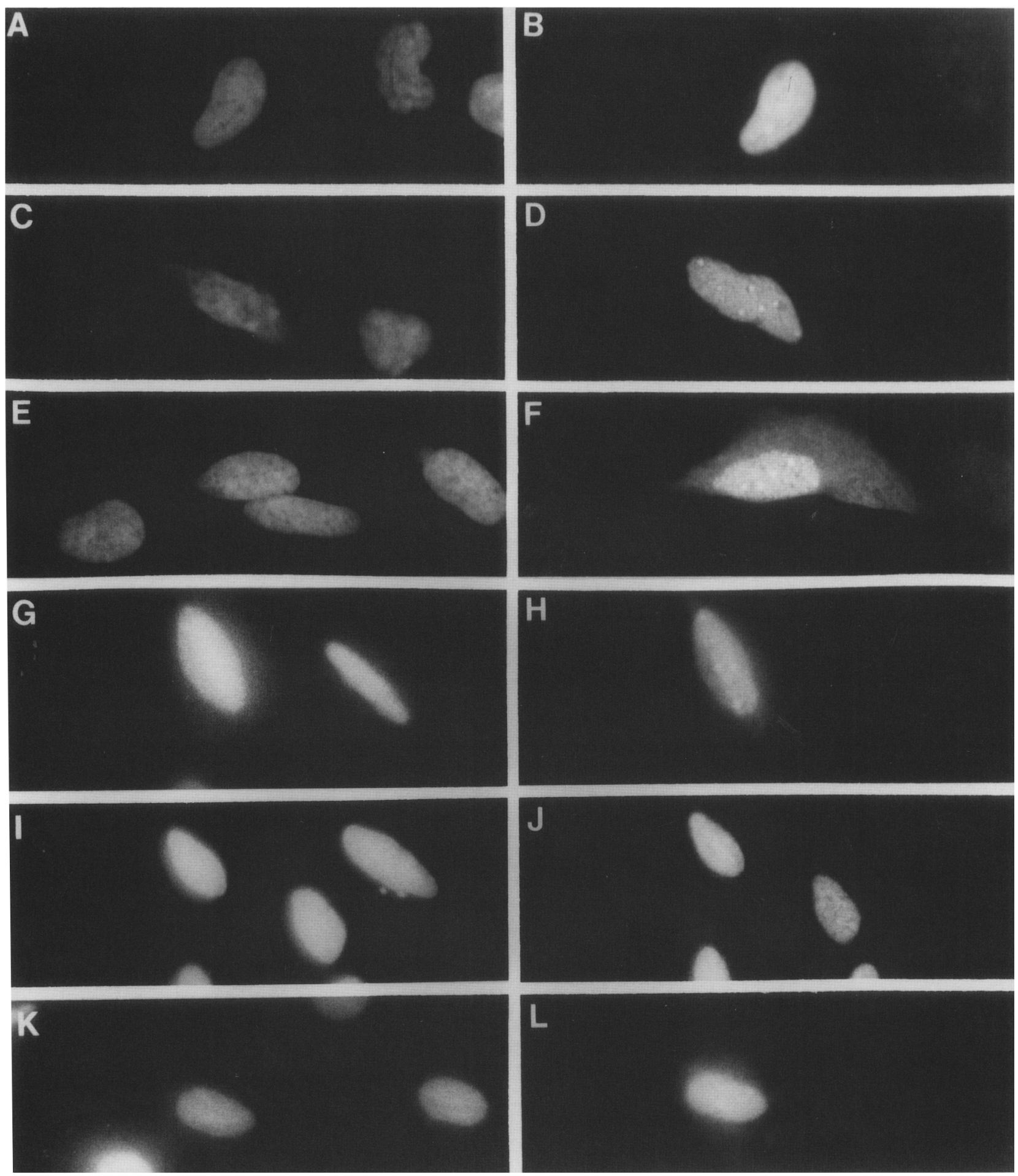

Figure 4. Immunofluorescence micrographs of transfected SAOS2 cells doubly stained with DAPI for DNA $(A, C, E, G, I, K)$ and with an antibody to RB $(B, D, F, H, J, L) .(A, B)$ SAOS2 cells transfected with pCMV-RB $(379-928) ;(C, D)$ pCMV-RB $(379-928,706 \mathrm{C} \rightarrow \mathrm{F}) ;(E, F)$ pCMV-RB(379-792); $(G, H)$ pCMV-RB(dl22); $(I, I)$ pCMV-RB(773-928); $(K, L)$ pCMV-RB(379-817).

shown in Figure 5B, the minimal pocket was inactive in this assay, unlike its wild-type, full-length $R B$ counterpart. The same was true in 0SH50-T cells (data not shown). This difference cannot be ascribed to failure to produce enough nuclear RB(379-792), because, as shown earlier (Fig. 1B), the relevant plasmids led to the synthe- 
A

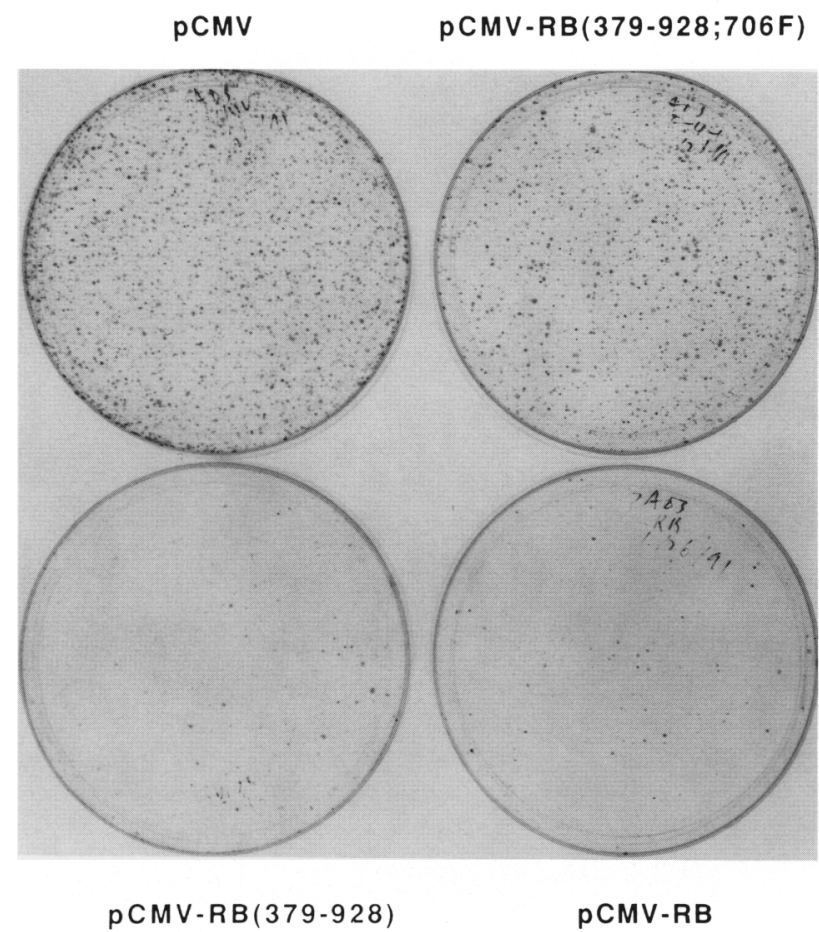

B

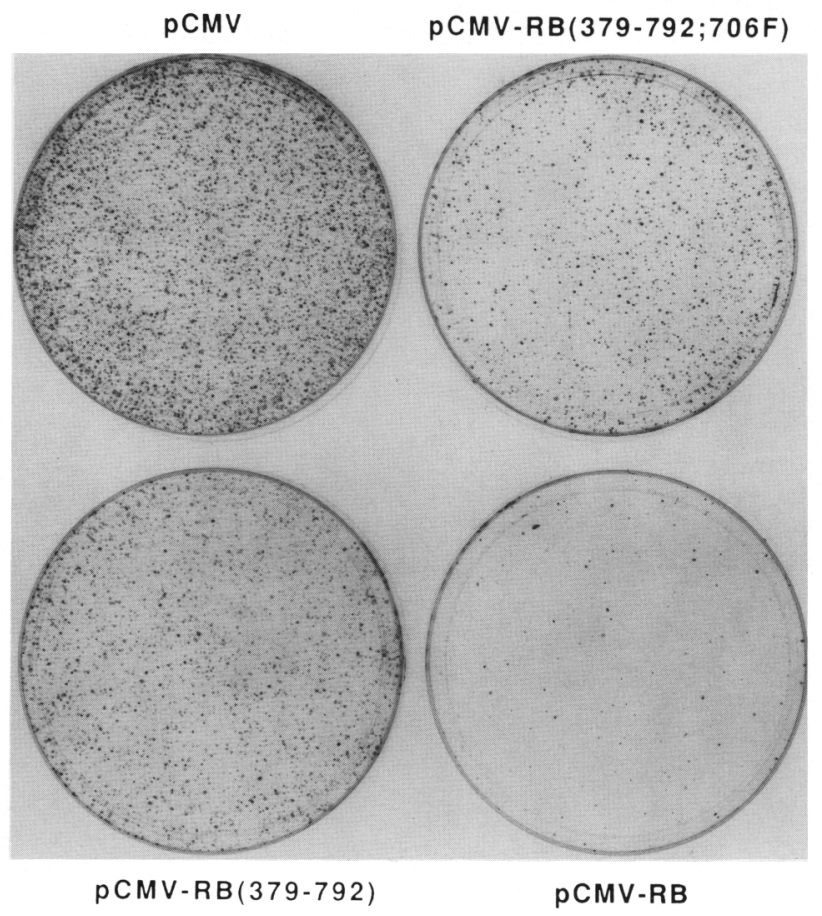

Figure 5. Growth assay of transfected SAOS2 cells. $|A, B|$ Cells were transfected with $30 \mu \mathrm{g}$ of the indicated plasmids and grown in the presence of G418 for $\sim 2$ weeks. G418 $8^{\mathrm{r}}$ colonies were then stained with crystal violet.

sis of comparable amounts of $\mathrm{RB}(379-792)$ and $\mathrm{RB}(379$ 928) and both of the proteins were similarly concentrated in the nucleus as determined by immunofluorescence (Fig. 4F and $\mathrm{B}$, respectively). To exclude the possibility that the addition of a few residues carboxyterminal to the RB pocket would enable the T/E1A-bind- ing domain to suppress cell growth in this assay or that the carboxyl terminus alone is sufficient to suppress cell growth, we repeated the above experiments with pCMV plasmids encoding RB residues 379-816 and 773-928. Both plasmids directed the synthesis of apparently unphosphorylated nuclear proteins, as determined by West-
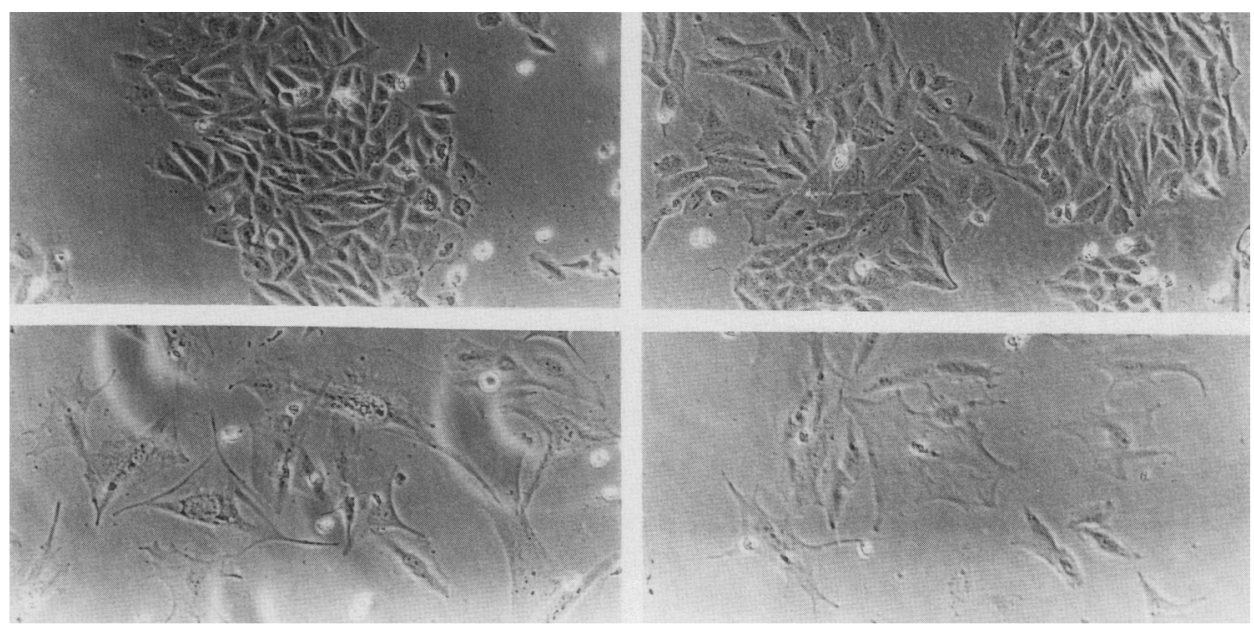

Figure 6. Phase-contrast micrographs $(340 \times) 12$ days after G418 selection showing morphologies of SAOS2 cells transfected with the indicated plasmids. 
ern blot and immunofluorescence analysis, and were expressed at levels equal to or exceeding those observed with $\mathrm{RB}(379-928)$ (Fig. 4L and J, respectively, and data not shown). In the case of RB(379-816), the absence of phosphorylation was confirmed in orthophosphate-labeling experiments (data not shown). As was demonstrated with $\mathrm{RB}(379-792)$, no evidence of growth suppression in SAOS2 cells was observed for either RB(379-816) or $\mathrm{RB}(773-928$ ) (data not shown). Cotransfection of plasmids encoding $\mathrm{RB}(379-928,706 \mathrm{C} \rightarrow \mathrm{F})$ and $\mathrm{RB}(379-$ 792 ), at varying molar ratios, likewise failed to lead to growth suppression in this assay (data not shown). This suggests that the pocket and the carboxyl terminus may not operate in trans.

\section{In vitro binding of truncated $R B$ proteins to $E 2 F$}

The failure of $R B(379-792)$ and $R B(379-816)$ to suppress colony formation in the transfection assays described above suggests that carboxy-terminal residues outside of the minimal pocket region (i.e., residues 816-928) may contribute an important component of RB growth suppression function. As RB interacts with a transcription factor, E2F, thought to play a role in regulating cell growth, we asked whether the ability of the RB derivatives, described above, to suppress cell growth might correlate with their ability to bind to E2F in vitro. Gelretardation assays were performed using nuclear extracts prepared from an $\mathrm{RB}-/$ - cell line (SAOS2) and a ${ }^{32} \mathrm{P}$ labeled oligonucleotide probe corresponding to a known E2F-binding site within the dihydrofolate reductase (DHFR) promoter (Hiebert et al. 1991). Approximately equal amounts of bacterially produced glutathione $S$-transferase (GST)-RB fusion proteins, containing RB residues $379-792 ; 379-816 ; 379-928 ; 379-928,706$ $\mathrm{C} \rightarrow \mathrm{F} ; \mathrm{RB}(\mathrm{dl22}$ ) (deletion of exon 22); or 773-928, were added to the reaction mixtures, and protein-DNA complexes were then electrophoresed in a nondenaturing polyacrylamide gel (Fig. 7). The complex indicated by the arrow in Figure 7 was shown previously to be "free" E2F (Bagchi et al. 1990; Shirodkar et al. 1992). Addition of GST-RB(379-928) resulted in a quantitative supershift of the free E2F species to yield a new complex of slower mobility (Fig. 7), indicating that the RB(379-928) segment can bind E2F efficiently in this assay. In contrast, other truncated or mutated GST-RB fusion proteins either failed to alter the mobility of E2F or did so less efficiently, suggesting that these RB species do not form stable complexes with E2F. It should also be noted that a longer exposure of the experiment in Figure 7 revealed a faint supershifted E2F band with GST-RB(379-792). Additional in vitro-binding assays, in which GST-RB(379792) and GST-RB(379-928) were assayed for E2F-binding activity, demonstrated levels of E2F binding to the former that were significant but $\sim 10$-fold lower than that observed for the latter (data not shown).

The results of these binding assays (summarized in Fig. 8) suggest that part or all of the 792-928 segment of $R B$ is required for efficient in vitro association with the transcription factor E2F. However, the carboxy- terminal

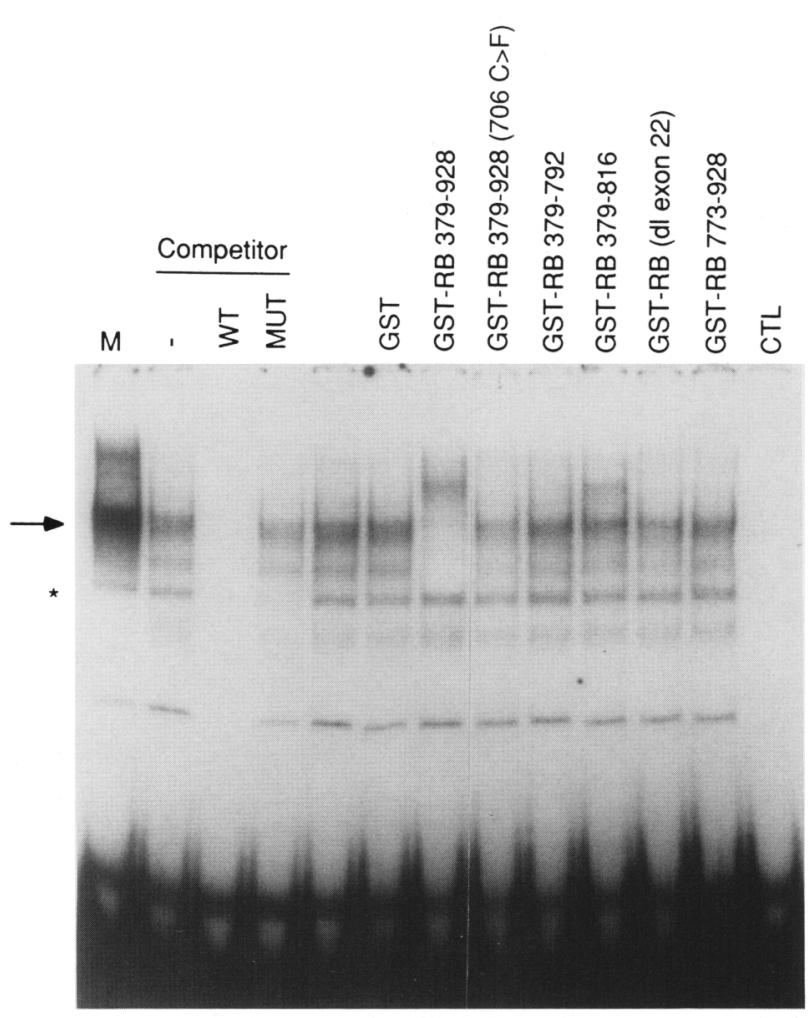

Figure 7. Binding of RB fusion proteins to E2F, as detected by gel retardation analysis. DNA-binding reactions contained nuclear extract prepared from SAOS 2 cells and a ${ }^{35} \mathrm{P}$-labeled oligonucleotide probe encoding the E2F DNA-binding site within the DHFR promoter. Specificity of the complexes was demonstrated by the addition of a 100-fold molar excess of unlabeled competitor oligonucleotide DNA representing either the wildtype (WT) or mutant (MUT) DHFR E2F-binding site. (Lane M) A control binding reaction with a previously characterized nuclear extract prepared from U937 (human) cells, which serves as a mobility marker for E2F complexes. The arrow indicates the position of a band corresponding to free E2F; the asterisk $\left({ }^{*}\right)$ denotes a nonspecific band. Purified, bacterially expressed GST or the indicated GST-RB fusion protein species was added to the DNA-binding reactions. Protein-DNA complexes were resolved by electrophoresis on $4 \%$ polyacrylamide gels. (Lane CTL) A control binding reaction containing GST-RB(379-928) and the probe without any SAOS2 nuclear extract.

$\mathrm{RB}$ segment, alone, is not sufficient for the interaction with E2F because GST-RB(773-928) failed to bind E2F in this assay (Fig. 7). In addition, consistent with previous findings (Bandara and La Thangue 1991; Chittenden et al. 1991; Hiebert et al. 1992), the integrity of the RB pocket is also required for efficient E2F binding, because GST-RB proteins harboring mutations within the pocket domain, $\mathrm{RB}(379-928,706 \mathrm{C} \rightarrow \mathrm{F})$ and $\mathrm{RB}(\mathrm{dl} 22)$, were defective for binding E2F (Figs. 7 and 8). Therefore, the ability to bind E2F efficiently in vitro correlates, at least in the cases examined here, with the ability to suppress cell growth in vivo (see Fig. 8).

\section{Discussion}

These findings indicate that more than the minimal 
Qin et al.

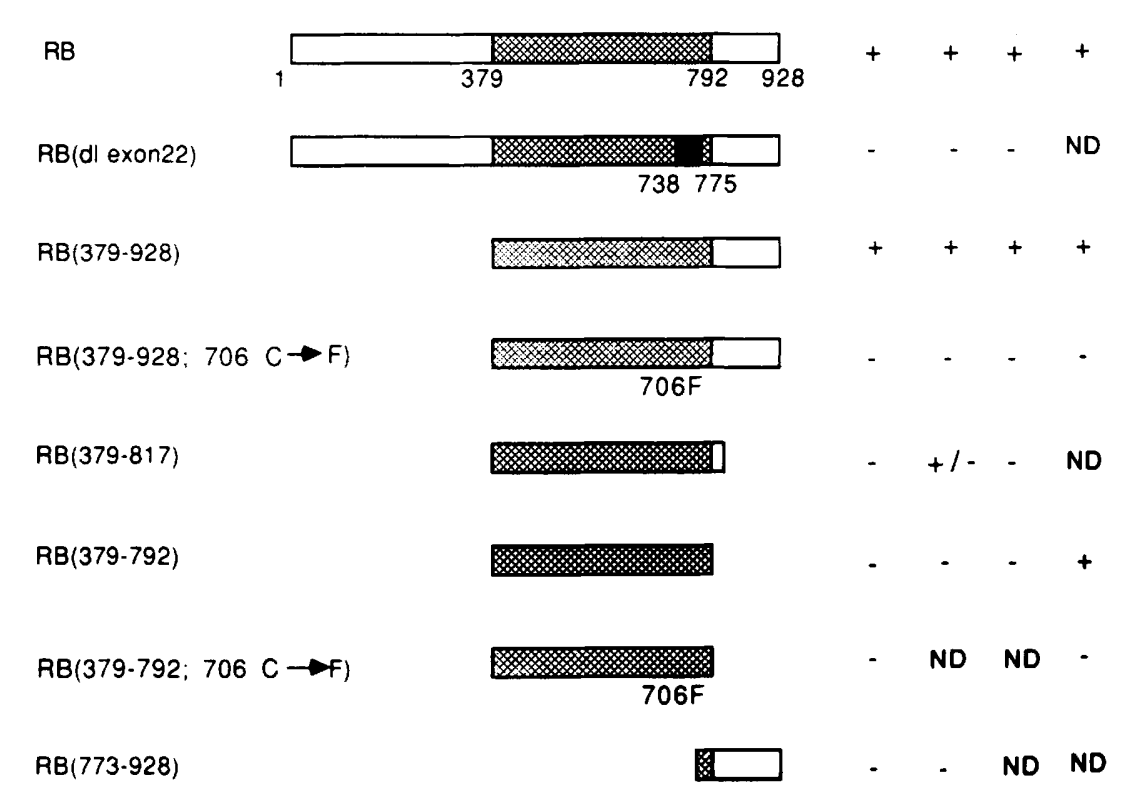

Figure 8. Summary of growth suppression, phosphorylation, $\mathrm{T}$ binding, and E2F binding data.

$\mathrm{RB}(773-928)$

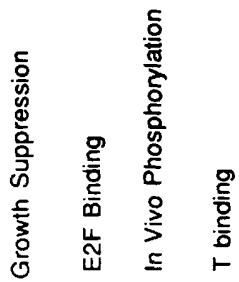

pocket domain is needed for RB-mediated growth suppression in cells that lack RB function. The additional sequences lie at the carboxyl terminus of the protein and are not essential for the binding of T, E1A, and most of the cellular proteins that have been identified as pocketbinding elements to date ( $\mathrm{Hu}$ et al. 1990; Huang et al. 1990; Kaelin et al. 1991). However, we must add that the in vitro assays performed thus far (Kaelin et al. 1991) may have failed to detect physiologically important differences in the ability of one or more cellular proteins to bind to the minimal pocket domain and to this domain linked to a normal carboxy-terminal segment. In this regard, the gel-shift assays described above suggest that the transcription factor E2F binds less efficiently to $\mathrm{RB}(379-792)$ than to $\mathrm{RB}(379-928)$. Similar results have been obtained by others (Hiebert et al. 1992). E2F is strongly suspected of regulating the $G_{1}$ exit process (Mudryi et al. 1990; Shirodkar et al. 1992), and indirect evidence suggests that $\mathrm{RB}$ may modulate its function (Hiebert et al. 1992). Thus, given the correlation between E2F binding and growth suppression, one might hypothesize that the ability of the RB polypeptides studied here to suppress cell growth is the result of their ability to bind to and modulate E2F in vivo. It is also possible that the carboxyl terminus provides a function essential to $\mathrm{RB}$ growth suppression that is unrelated to E2F binding and separate from that of the pocket.

The data also indicate that sequences outside of the minimal pocket domain are essential for overt RB phos- phorylation. This observation is consistent with earlier work by Hamel et al. (1990). Yet, it is obvious that lack of phosphorylation is not the sole basis for the absence of minimal pocket growth suppression, for the un(der)phosphorylated RB species is the predominant one observed in the $\mathrm{RB}-1$ - cells transfected with /and growth arrested by) either full-length $\mathrm{RB}$ or $\mathrm{RB}(379-928)$. On the other hand, it is currently not possible to rule out the hypothesis that cell cycle-dependent phosphorylation contributes to an orderly expression of $\mathrm{RB}$ functions over time. In this regard, it is noteworthy that to date, all spontaneously occurring, loss-of-function RB mutants, which encode stable proteins, are hypophosphorylated in vivo (Horowitz et al. 1989, 1990; Bookstein et al. 1990; Kaye et al. 1990; Shew et al. 1990a,b; Scheffner et al. 1991). Given the results of the growth suppression assay, perhaps the simplest explanation for the apparent lack of phosphorylation of either $\mathrm{RB}(379-928)$ or full-length $\mathrm{RB}$ in the $\mathrm{RB}-/$ - cells is that the recipient cells are growth arrested in $G_{1}$, that is, that time in the cell cycle when $\mathrm{RB}$ normally exists in an un- or underphosphorylated form (Buchkovich et al. 1989; Chen et al. 1989; DeCaprio et al. 1989; Mihara et al. 1989; Xu et al. 1989). In support of this hypothesis, Goodrich et al. (1991) have recently demonstrated that microinjection of a recombinant RB protein spanning residues $394-928$ is sufficient to induce $G_{1}$ growth arrest in $R B-/-$ cells. Among several alternative explanations would be an inherent inability of the $\mathrm{RB}-/-$ cells chosen for this study to 
phosphorylate an exogenous RB substrate. Experiments are under way to address these possibilities.

As has been observed previously upon reintroduction of a wild-type p53 allele into p53 $+/+$ cells (Baker et al. 1990; Johnson et al. 1991) and after reintroducing fulllength RB into RB $+1+$ cells (Huang et al. 1988), we failed to detect any growth perturbation when the various wild-type RB-encoding plasmids were introduced into U20S $(\mathrm{RB}+/+)$ cells. Although the molecular explanation for this phenomenon has not been elucidated, it remains a formal possibility that the transformed cells studied here have sustained one or more mutations that render them immune to the growth suppression functions of RB.

In summary, much of the RB-coding sequence /residues $1-379$ ) is not necessary for either overt RB phosphorylation, the presence of differentially phosphorylated RB species, $T$ and E2F binding, or the ability of RB to grossly suppress the growth of certain $\mathrm{RB}(-/-)$ cell lines. In contrast, the action of the RB pocket and, presumbably, its ability to form complexes with one or more specific cellular proteins is necessary, in support of the prior speculation on this matter. However, it is not sufficient for RB-mediated growth suppression, as assayed here. A second function, provided by sequences carboxy-terminal to the pocket, is also required, although the nature of this function is presently unclear. In this regard, we have demonstrated that the carboxyl terminus of $\mathrm{RB}$ is required for the pocket to interact efficiently with E2F, at least as measured by gel-shift activity. Hence, given the correlations described in Figure 8, E2F binding might provide one potential explanation for the requirement of the carboxyl terminus in the biological assays described here.

Importantly, in comparing the sequences of the RB proteins of several species-human, mouse, and Xenopus (Bernards et al. 1989; S. Friend and O. Destree, pers. comm.), it is clear that there is greater homology among the pocket and carboxy-terminal segments of all of these species than among the amino-terminal portions, suggesting that whatever its mode of action, the carboxyl terminus contributes to a core RB function. Of immediate interest will be determination of whether the carboxyl terminus operates by contributing to the function of the pocket or by performing a wholly different function.

\section{Materials and methods}

Cells

U20S, SAOS2, and MDA-MB-468 cells were obtained from the American Type Culture Collection. MEF $\Psi$ T, MEF $\Psi$ K1, and A31 cells were our own laboratory stock. OHS50-T cells were kindly provided by Steve Friend. All of the cells were grown in Dulbecco's modified Eagle medium (DMEM) (Sigma) containing $12 \%$ fetal calf serum in a $10 \% \mathrm{CO}_{2}$-containing atmosphere.

\section{Construction of plasmids}

The generation of cDNAs encoding RB residues 379-792, 379817 , and $379-928$, as well as a $706 \mathrm{C} \rightarrow \mathrm{F}$ mutant derivative of the latter, has been described previously (Kaelin et al. 1990, 1991). An RB cDNA encoding 379-792 with the 706F mutation was also generated by polymerase chain reaction (PCR) by use of the primers and PCR conditions described previously /Kaelin et al. 1990). These cDNAs were subcloned into the unique $\mathrm{BamHI}$ site of the pCMV-Neo-Bam vector (Baker et al. 1990). The construction of pGEX plasmids encoding pGT-RB(379-792), pGT$\mathrm{RB}(379-928)$, and pGT-RB(379-928,706 C $\rightarrow$ F) has been described previously (Kaelin et al. 1991). A full-length RB cDNA, a mutant version in which exon 22 was deleted, as well as the 379-817 cDNA described above, was also subcloned into pCMV-Neo-Bam and a modified pGEX plasmid, pGEX-2TK (W. Kaelin and $M$. Blanar, unpubl.). The exon 22 mutant was generated by cutting the full-length $\mathrm{RB}$ cDNA at unique NcoI and Bsml sites, and inserting the Ncol-BsmI fragment from pGEX-2T-RB(379-928; d122) (Kaelin et al. 1991). An RB cDNA encoding 773-928 was generated by PCR using the primers 5'-GCGCGGATCCTCATTTCTCTTCCTTGTTTGAGG$3^{\prime}$ (DN74) and 5'-GCGCGGATCCGCCACCATGTCCACCAGGCCCCCTACCTTG-3' (Rb773S). The PCR conditions for generating this cDNA were as described (Kaelin et al. 1990), except that the annealing temperature was $55^{\circ} \mathrm{C}$ and the amplification proceeded for 35 cycles. This cDNA was subcloned into pCMV-Neo-Bam vector and sequenced by DyeDeoxy Terminator method (Pharmacia).

\section{Transfection}

Cells were transfected at $\sim 70 \%$ confluence with $30 \mu \mathrm{g}$ of plasmid DNA by the calcium phosphate method, as described by DeCaprio et al. (1988). The medium was changed twice, $16 \mathrm{hr}$ after transfection.

\section{Western blot analysis}

Thirty-six hours after transfection, cells were lysed in EBC buffer (50 mm Tris at $\mathrm{pH} 8.0,120 \mathrm{~mm} \mathrm{NaCl}, 0.5 \% \mathrm{NP}-40$ ), as described previously (DeCaprio et al. 1988), and protein concentrations were determined by the Bio-Rad protein assay. Approximately $60 \mu \mathrm{g}$ of total protein was loaded per lane, resolved in a SDS-polyacylamide gel, and transferred to polyvinylidene difluoride (PVDF) membranes (Millipore) in Tris/glycine/methanol buffer for $4 \mathrm{hr}$ (DeCaprio et al. 1988). Membranes were incubated overnight with a monoclonal antibody directed against human RB (XZ91 or XZ56) [1:3 dilution of hybridoma supernatant in TBS (10 mM Tris at pH $8.0,150 \mathrm{~mm} \mathrm{NaCl})$ containing $5 \%$ BSA]. The membranes were washed with TBS plus $0.5 \%$ BSA and probed with an alkaline phosphatase-conjugated goat anti-mouse antibody (Fisher), as described by the manufacturer.

\section{${ }^{35} S$-labeling and immunoprecipitation}

For ${ }^{35} \mathrm{~S}$-labeling, cells were starved in methionine-free DMEM for $0.5 \mathrm{hr}$ and then fed with DMEM containing $\left[{ }^{35} \mathrm{~S} \mid\right.$ methionine (1140 Ci/mmole, New England Nuclear) at a concentration of $200 \mu \mathrm{Ci} / \mathrm{ml}$ for $3 \mathrm{hr}$.

Preparation of cell extracts and immunoprecipitation reactions were performed as described previously (DeCaprio et al. 1988).

\section{${ }^{32}$ P-Labeling and alkaline phosphatase analyses}

Cells were metabolically labeled in $3 \mathrm{ml}$ of serum-free, phosphate-free DMEM supplemented with $1 \mathrm{mCi}$ of $\left[{ }^{32} \mathrm{P}\right]$ orthophosphate (New England Nuclear) per milliliter of culture medium for $3 \mathrm{hr}$ at $37^{\circ} \mathrm{C}$. Aliquots of cell lysate were immunoprecipi- 
tated with XZ91 (Hu et al. 1991) (hybridoma supernatant). Protein A-Sepharose bead-bound proteins were resolved in $7.5 \%$ SDS-polyacrylamide gels, transferred to PVDF membranes, and detected by immunoblotting with XZ91 followed by autoradiography.

For phosphatase treatment experiments, the protein A-Sepharose was resuspended in $50 \mu \mathrm{l}$ of $1 \times$ alkaline phosphase buffer (50 mM Tris at pH 8.5, $0.1 \mathrm{~mm}$ EDTA) to which was added 6 units of alkaline phosphatase (Boehringer Mannheim) and the following protease inhibitors: $2 \mu \mathrm{g} / \mathrm{ml}$ of aprotinin, $2 \mu \mathrm{g} / \mathrm{ml}$ of phenylmethylsulfonylfluoride, and $20 \mu \mathrm{g} / \mathrm{ml}$ of leupeptin. After a 2 -hr incubation at $37^{\circ} \mathrm{C}$, an additional 6 units of enzyme were added to the reaction mix, and the reaction was allowed to proceed for an additional hour at $56^{\circ} \mathrm{C}$. Control reaction mixtures contained either no enzyme or the phosphatase inhibitors sodium orthovanadate $(10 \mathrm{~mm})$ and sodium fluoride $(2 \mathrm{~mm})$.

\section{Immunofluorescence}

Cells were grown on glass coverslips in $60-\mathrm{mm}$ dishes before transfection. After transfection, cells were washed with PBS ( $137 \mathrm{~mm} \mathrm{NaCl}, 3 \mathrm{~mm} \mathrm{KCl}, 5 \mathrm{mM} \mathrm{Na} 2 \mathrm{HPO}_{4}$, and $2 \mathrm{mM} \mathrm{KH}_{2} \mathrm{PO}_{4}$ at $\mathrm{pH} 7.4$ ), fixed with $0.5 \%$ paraformaldehyde solution for 15 min on ice, and permeabilized with methanol at $25^{\circ} \mathrm{C}$. After three washes in PBS, cells were incubated with an appropriate dilution $(1: 1)$ of primary antibody (hybridoma supernatants: $\mathrm{XZ91}$ for $\mathrm{RB}(379-792), \mathrm{RB}(379-928)$, their $706 \mathrm{C} \rightarrow \mathrm{F}$ mutant derivatives, and 379-816; XZ56 (Hu et al. 1991) for RB(773-928) and $\mathrm{RB}(\mathrm{dl} 22)$ in PBS containing $5 \%$ goat serum at $25^{\circ} \mathrm{C}$ for $1 \mathrm{hr}$. The second antibody [FITC-conjugated goat anti-mouse antibody (Boehringer Mannheim), l : 10 dilution in PBS] incubation was performed at $25^{\circ} \mathrm{C}$ for $45 \mathrm{~min}$. Cells were then washed with PBS, stained for DNA with $0.5 \mu \mathrm{g} / \mathrm{ml}$ of $4^{\prime}-6$-diamidino-2-phenylindole hydrochloride (DAPI), mounted, and examined by fluoromicroscopy.

\section{Colony formation assay}

Cells that had achieved $\sim 70 \%$ confluence were transfected with either the pCMV-Neo-Bam parental plasmid or the various RB-encoding derivatives. The cell growth media were supplemented with G418 $(300 \mu \mathrm{g} / \mathrm{ml}) 48 \mathrm{hr}$ later. Approximately 2 weeks later, when macroscopic colonies became detectable, the cells were washed with PBS, fixed in $10 \% \mathrm{HOAc} / 10 \% \mathrm{MeOH}$ for $15 \mathrm{~min}$, and stained with $0.4 \%$ crystal violet, $20 \% \mathrm{EtOH}$, for $15 \mathrm{~min}$.

\section{E2F mobility-shift assay}

Nuclear extracts from SAOS2 cells were prepared by the procedure of Schreiber et al. (1989). E2F gel mobility-shift assays were performed essentially as described by Shirodkar et al. (1992). GST-RB fusion proteins were synthesized in bacteria $(200-\mathrm{m}]$ cultures) as described by Kaelin et al. (1991), purified by adsorption to $100 \mu \mathrm{l}$ of glutathione-Sepharose beads, and eluted by incubation $\left(5 \mathrm{~min}\right.$ at $\left.4^{\circ} \mathrm{C}\right)$ in $100 \mu \mathrm{l}$ of elution buffer $(100 \mathrm{mM}$ Tris at $\mathrm{pH} 8.0,120 \mathrm{~mm} \mathrm{NaCl}, 20 \mathrm{~mm}$ reduced glutathione). Two microliters of each purified fusion protein, containing approximately equal amounts $(\sim 30 \mathrm{ng})$ as estimated by Coomassie blue-stained gels, was added to DNA-binding reactions just before the addition of the probe. The E2F probe was a synthetic oligonucleotide corresponding to the E2F-binding site defined within the DHFR promoter (Hiebert et al. 1991). It was ${ }^{32} \mathrm{P}$-endlabeled by T4 polynucleotide kinase. The DNA sequences of the wild-type DHFR oligonucleotide and a corresponding oligonucleotide containing mutations within the E2F DNA-binding se- quences are as follows (+ strand): DHFR WT, CTAGTGCAATTTCGCGCCAAACTTG; DHFR MUT, CTAGTGCAATTGCTCGACCAACTTG. Binding reactions were analyzed by electrophoresis in $4 \%$ polyacrylamide gels run in $0.25 \times \mathrm{TBE}(22$ $\mathrm{mM}$ Tris, $22 \mathrm{~mm}$ boric acid, $0.5 \mathrm{~mm}$ EDTA) at $4^{\circ} \mathrm{C}$.

\section{Acknowledgments}

We thank Drs. Bert Vogelstein and Eric Fearon for the pCMVNeo-Bam plasmid; Dr. Edward Harlow for the XZ91 and XZ56 monoclonal antibodies directed against human RB; Dr. Jim DeCaprio for help with the immunofluorescence staining; Dr. Mark Ewen for providing the RB773S primer; Lori Wirth for DNA sequencing; and our colleagues at the Institute for their many helpful comments. This work was supported by grants from the National Institutes of Health to D.M.L., T.C., and W.G.K..

The publication costs of this article were defrayed in part by payment of page charges. This article must therefore be hereby marked "advertisement" in accordance with 18 USC section 1734 solely to indicate this fact.

\section{References}

Bagchi, S., P. Raychaudhuri, and J.R. Nevins. 1990. Adenovirus ElA can dissociate heteromeric complexes involving the E2F transcription factor: A novel mechanism for E1A transactivation. Cell 62: 659-669.

Bagchi, S., R. Weinmann, and P. Raychaudhuri. 1991. The retinoblastoma protein copurifies with E2F-I, an E1A-regulated inhibitor of the transcription factor E2F. Cell 65: 1063-1072.

Baker, S.J., S. Markowitz, E. Fearon, B. Willson, and B. Vogelstein. 1990. Suppression of human colorectal carcinoma cell growth by wild-type p53. Science 249: 912-915.

Bandara, L.R. and N.B. La Thangue. 1991. Adenovirus E1A prevents the retinoblastoma gene product from complexing with a cellular transcription factor. Nature 351: 494-497.

Benedict, W.F., A.L. Murphee, A. Banerjee, C.A. Spina, M.C. Sparkes, and R.S. Sparkes. 1983. Patient with chromosome 13 deletion: Evidence that the retinoblastoma gene is a recessive cancer gene. Science 219: 973-975.

Bernards, R., G.M. Schackleford, M.R. Gerber, J.M. Horowitz, S.H. Friend, M. Schartl, E. Bogenmann, J.M. Rapaport, T. McGee, T.P. Dryia, and R.A. Weinberg. 1989. Structure and expression of the murine retinoblastoma gene and characterization of its encoded protein. Proc. Natl. Acad. Sci. 86: 6474-6478.

Bookstein, R., J. Shew, P. Chen, P. Scully, and W. Lee. 1990. Suppression of tumorigenicity of human prostate carcinoma cells by replacing a mutated RB gene. Science 247: 712-715.

Buchkovich, K., L.A. Duffy, and E. Harlow. 1989. The retinoblastoma protein is phosphorylated during specific phases of the cell cycle. Cell 58: 1097-1105.

Cavenee, W.K., T.P. Dryia, R.A. Phillips, W.F. Benedict, R. Godbout, B.L. Gallie, A.L. Murphree, L.C. Strong, and R.L. White. 1983. Expression of recessive alleles by chromosomal mechanisms in retinoblastoma. Nature 305: 779-784.

Chellappan, S.P., S. Hiebert, M. Mudryi, J.M. Horowitz, and J.R. Nevins. 1991. The E2F transcription factor is a cellular target for the RB protein. Cell 65: 1053-1061.

Chen, S. and E. Paucha. 1990. Identification of a region of simian virus 40 large $T$ antigen required for cell transformation. I. Virol. 64: 3350-3357.

Chen, P., P. Scully, J. Shew, J.Y.J. Wang, and W. Lee. 1989. 
Phosphorylation of the retinoblastoma gene product is modulated during the cell cycle and cellular differentiation. Cell 58: 1193-1198.

Chittenden, T., D.M. Livingston, and W.G.J. Kaelin. 1991. The T/E1A-binding domain of the retinoblastoma product can interact selectively with a sequence-specific DNA-binding protein. Cell 65: 1073-1082.

DeCaprio, J.A., J.W. Ludlow, J. Figge, J.-Y. Shew, C.-M. Huang, W.-H. Lee, E. Marsilio, E. Paucha, and D.M. Livingston. 1988. SV40 large $T$ antigen forms a specific complex with the product of the retinoblastoma susceptibility gene. Cell 54: 275-283.

DeCaprio, J.A., J.W. Ludlow, D. Lynch, Y. Furukawa, J. Griffin, H. Piwnica-Worms, C.-M. Huang, and D.M. Livingston. 1989. The product of the retinoblastoma susceptibility gene has properties of a cell cycle regulatory element. Cell 58: 1085-1095.

Diller, L., I. Kassel, C. Nelson, M. Gryka, G. Litwak, M. Gebhardt, B. Bressac, M. Ozturk, S. Baker, B. Vogelstein, and S. Friend. 1990. p53 functions as a cell cycle control protein in osteosarcoma. Mol. Cell. Biol. 10: 5772-5781.

Ewen, M.E., J.W. Ludlow, E. Marsilio, J.A. DeCaprio, R.C. Millikan, S. Cheng, E. Paucha, and D.M. Livingston. 1989. An $\mathrm{N}$-terminal transformation-governing sequence of SV40 large $T$ antigen contributes to the binding of both p110RB and a second cellular protein, p120. Cell 58: 257-267.

Ewen, M.E., B. Faha, E. Harlow, and D.M. Livingston. 1992. Interaction of p107 with cyclin A independent of complex formation with viral oncoproteins. Science 255: 85-87.

Friend, S.H., R. Bernards, S. Rogelj, R.A. Weinberg, J.M. Rapaport, D.M. Alberts, and T.P. Dryja. 1986. A human DNA segment with properties of the gene that predisposes to retinoblastoma and osteosarcoma. Nature 323: 643-646.

Fung, Y.-K.T., A.L. Murphree, A. T'Ang, J. Qian, S.H. Hinrichs, and W.F. Benedict. 1987. Structural evidence for the authenticity of the human retinoblastoma gene. Science 236: 16571661.

Godbout, R., T.P. Dryja, J. Squire, B.L. Gallie, and R.A. Phillips. 1983. Somatic inactivation of genes on chromosome 13 is a common event in retinoblastoma. Nature 304: 451-453.

Goodrich, D.W., N.P. Wang, Y.-W. Qian, E.Y.-H.P. Lee, and W.H. Lee. 1991. The retinoblastoma gene product regulates progression through the Gl phase of the cell cycle. Cell 67: 293-302.

Hamel, P.A., B.L. Cohen, L.M. Sorce, B.L. Gallie, and R.A. Phillips. 1990. Hyperphosphorylation of the retinoblastoma gene product is determined by domains outside the simian virus 40 large-T-antigen-binding regions. Mol. Cell. Biol. 10: 6586-6595.

Harlow, E., L.V. Crawford, D.C. Pim, and N.M. Williamson. 1981. Monoclonal antibodies specific for simian virus 40 tumor antigens. J. Virol. 39: 861-869.

Hiebert, S.W., M. Blake, J. Azizkhan, and J.R. Nevins. 1991. Role of E2F transcription factor in E1A-mediated trans activation of cellular genes. J. Virol. 65: 3547-3552.

Hiebert, S.W., P. Srikumar, S.P. Chellappan, J.M. Horowitz, and J.R. Nevins. 1992. The interaction of pRB with E2F coincides with an inhibition of the transcriptional activity of E2F. Genes \& Dev. 6: 177-185.

Horowitz, J.M., D.W. Yandell, S. Park, S. Canning, P. Whyte, K. Buchkovich, E. Harlow, R.A. Weinberg, and T.P. Dryja. 1989. Point mutational inactivation of the retinoblastoma antioncogene. Science 243: 937-940.

Horowitz, J.M., S. Park, E. Bogenmann, J. Cheng, D.W. Yandell, F.J. Kaye, J.D. Minna, T.P. Dryja, and R.A. Weinberg. 1990. Frequent inactivation of the retinoblastoma anti-oncogene is restricted to a subset of human tumor cells. Proc. Natl. Acad. Sci. 87: 2775-2779.

$\mathrm{Hu}$, Q., N. Dyson, and E. Harlow. 1990. The regions of the retinoblastoma protein needed for binding to adenovirus ElA or SV40 large T antigen are common sites for mutations. $E M B O$ I. 9: 1147-1155.

Hu, Q., C. Bautista, G.M. Edwards, D. Defeo-Jones, R.E. Jones, and E. Harlow. 1991. Antibodies specific of the human retinoblastoma protein identify a family of related polypeptides. Mol. Cell. Biol. 11: 5792-5799.

Huang, H.-J.S., J.-K. Yee, J.-Y. Shew, P.-L. Chen, R. Bookstein, T. Friedmann, E.Y.-H.P. Lee, and W.-H. Lee. 1988. Suppression of the neoplastic phenotype by replacement of the RB gene in human cancer cells. Science 242: 1563-1566.

Huang, S., N. Wang, B.Y. Tseng, W. Lee, and E.H. Lee. 1990. Two distinct and frequently mutated regions of retinoblastoma protein are required for binding to SV40 T antigen. EMBO I. 9: 1815-1822.

Huang, S., W.-H. Lee, and Y.-H.P. Lee. 1991. A cellular protein that competes with SV40 T antigen for binding the retinoblastoma gene product. Nature 350: 160-162.

Johnson, P., D. Gray, M. Mowat, and S. Benchimol. 1991. Expression of wild-type p53 is not compatible with continued growth of p53-negative tumor cells. Mol. Cell. Biol. 11: 111 .

Kaelin, W.G., M.E. Ewen, and D.M. Livingston. 1990. Definition of the minimal simian virus 40 large $T$ antigen- and adenovirus E1A-binding domain in the retinoblastoma gene product. Mol. Cell. Biol. 10: 3761-3769.

Kaelin, W.G., D.C. Pallas, J.A. DeCaprio, F.J. Kaye, and D.M. Livingston. 1991. Identification of cellular proteins that can interact specifically with the T/E1A-binding region of the retinoblastoma gene product. Cell 64: 521-532.

Kalderon, D. and A.E. Smith. 1984. In vitro mutagenesis of a putative DNA binding domain of SV40 large-T. Virology 139: 109-137.

Kaye, F.J., R.A. Kratzke, J.L. Gerster, and J.M. Horowitz. 1990. A single amino acid substitution results in a retinoblastoma protein defective in phosphorylation and oncoprotein binding. Proc. Natl. Acad. Sci.. 87: 6922-6926.

Knudson, A.G., Jr. 1971. Mutation and cancer: Statistical study of retinoblastoma. Proc. Natl. Acad. Sci. 68: 820-823.

Lee, E.Y.-H.P., H. To, J.-Y. Shew, R. Bookstein, P. Scully, and W.-H. Lee. 1988. Inactivation of the retinoblastoma susceptibility gene in human breast cancers. Science 241: 218-221.

Lee, W.-H., R. Bookstein, F. Hong, L.-J. Young, J.-Y. Shew, and E.Y.-H. P. Lee. 1987a. Human retinoblastoma susceptibility gene: Cloning, identification, and sequence. Science 235: 1394-1399.

Lee, W.-H., J.-Y. Shew, F.D. Hong, T.W. Sery, L.A. Donoso, L.-J. Young, R. Bookstein, and E.Y.-H.P. Lee. 1987b. The retinoblastoma susceptibility gene encodes a nuclear phosphoprotein associated with DNA binding activity. Nature 329: 642-645.

Ludlow, J.W., J.A. DeCaprio, C. Huang, W. Lee, E. Paucha, and D.M. Livingston. 1989. SV40 Large T antigen binds preferentially to an underphosphorylated member of the retinoblastoma susceptibility gene product family. Cell 56: 57-65.

Ludlow, J.W., J. Shon, J.M. Pipas, D.M. Livingston, and J.A. DeCaprio. 1990. The retinoblastoma susceptibility gene product undergoes cell cycle-dependent dephosphorylation and binding to and release from SV40 large T. Cell 60: 387-396.

Mihara, K., X. Cao, A. Yen, S. Chandler, B. Driscoll, A.L. Murphree, A. T'Ang, and Y. Fung. 1989. Cell cycle-dependent regulation of phosphorylation of the human retinoblastoma gene product. Science 246: 1300-1303. 
Qin et al.

Mittnacht, S. and R.A. Weinberg. 1991. Gl/S phosphorylation of the retinoblastoma protein is associated with an altered affinity for the nuclear compartment. Cell 65: 381-393.

Mudryj, M., S.W. Hiebert, and J.R. Nevins. 1990. A role for the adenovirus inducible E2F transcription factor in a proliferation dependent signal transduction pathway. EMBO $\mathrm{J}$. 9: 2179-2184.

Scheffner, M., K. Munger, J.C. Byrne, and P.M. Howley. 1991. The state of the p53 and retinoblastoma genes in human cervical carcinoma cell lines. Proc. Natl. Acad. Sci.. 88: 5523-5527.

Schreiber, E., P. Matthias, M.M. Muller, and W. Schaffner. 1989. Rapid detection of octamer binding proteins with "mini-extracts", prepared from a small number of cells. Nucleic Acids Res. 17: 6419.

Shew, J., P. Chen, R. Bookstein, E.Y. Lee, and W. Lee. 1990a. Deletion of a splice donor site ablates expression of the following exon and produces an unphosphorylated RB protein unable to bind SV40 T antigen. Cell Growth Differ. 1: 17-25.

Shew, J., B.T. Lin, P. Chen, B.Y. Tseng, T.L. Yang-Feng, and W. Lee. 1990b. C-terminal truncation of the retinoblastoma gene product leads to functional inactivation. Proc. Natl. Acad. Sci. 87: 6-10.

Shirodkar, S., M. Ewen, J.A. Decaprio, J. Morgan, and D.M. Livingston. 1992. The transcription factor E2F interacts with the retinoblastoma product and a p107-cyclin A complex in a cell cycle-regulated manner. Cell 68: 157-166.

Sparkes, R.S., A.L. Murphree, R.W. Lingua, M.C. Sparkes, L.L. Field, S.J. Funderburk, and W.F. Benedict. 1983. Gene for hereditary retinoblastoma assigned to human chromosome 13 by linkage to esterase D. Science 219: 971-973.

Takahashi, R., T. Hashimoto, H.-J. Xu, S.-X. Hu, T. Maatsui, T. Miki, H. Bigo-Marshall, S.A. Aaronson, and W.F. Benedict. 1991. The retinoblastoma gene functions as a growth and tumor suppressor in human bladder carcinoma cells. Proc. Natl. Acad. Sci.. 88: 5257-5261.

T'Ang, A., J.M. Varley, S. Chakraborty, A.L. Murphree, and Y.T. Fung. 1988. Structural rearrangement of the retinoblastoma gene in human breast cancer. Science 242: 263-266.

Templeton, D.J., S.H. Park, L. Lanier, and R. Weinberg. 1991. Nonfunctional mutants of the retinoblastoma protein are characterized by defects in phosphorylation, viral oncoprotein association, and nuclear tethering. Proc. Natl. Acad. Sci. 88: 3033-3037.

$\mathrm{Xu}, \mathrm{H}$., S. Hu, T. Hashimoto, R. Takahashi, and W.F. Benedict. 1989. The retinoblastoma susceptibility gene product: A characteristic pattern in normal cells and abnormal expression in malignant cells. Oncogene 4: 807-812. 


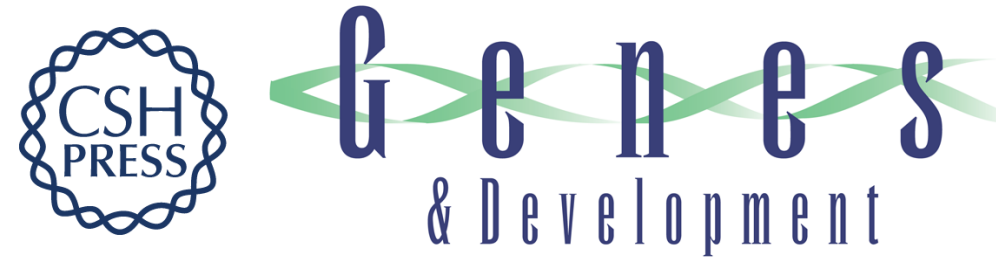

\section{Identification of a growth suppression domain within the retinoblastoma gene product.}

$X$ Q Qin, T Chittenden, D M Livingston, et al.

Genes Dev. 1992, 6:

Access the most recent version at doi:10.1101/gad.6.6.953

References This article cites 57 articles, 29 of which can be accessed free at:

http://genesdev.cshlp.org/content/6/6/953.full.html\#ref-list-1

License

Email Alerting

Service

Receive free email alerts when new articles cite this article - sign up in the box at the top right corner of the article or click here.

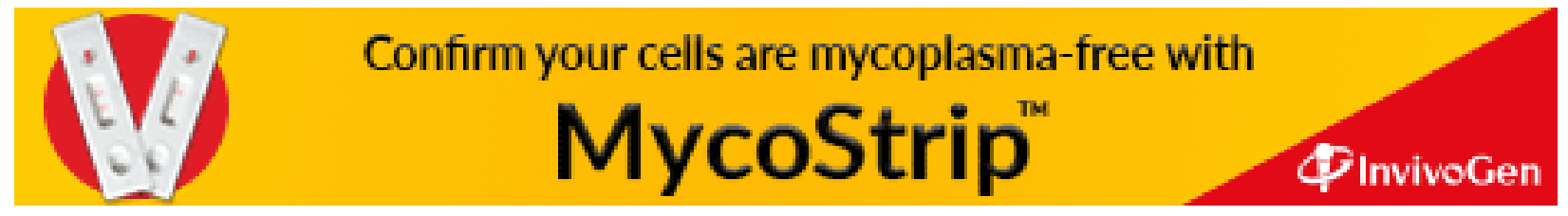

